$M R-114-04$

F. Ti. RACEY

Mining Ingineer

610 Paolfic Butlding

Vancouver, 3.0 .

\author{
c \\ 0 \\ way 6 th, 1938 .
}

\title{
Lettor of Transm1ttal
}

Hew Chlohagof Mining syndicate

- / Mr. J.J. Stooker, Preasurer

Juneau, Alagka.

aentzemen:

roliowine your instructions the writer spent llay $3 \mathrm{rd}, 4$ th, and 5 th, 1938, in making a geological examination of your alning property and undarground workinge altuated at the heed of Pinta Bay, Chlchagof Ialana, Mlaska.

The prinolpal object of this examination $19 a \mathrm{~s}$ to learn the hablt of ore deposition on your property and from thet to lay out a program for Iuture oxplorat1on. For this reason no examination was made of the olalm locationg nor title to thom.

In oarrying out this work, use was made of a transit survey plan of the underground workings kindly gupplied by Hr. P. M. Sorensen of the H1rgt-Ohlohagof mlne and a former sampling of the quartz ore bodie done by Mr. gorengen, Mr. B. D. 3tewart, Ur. B. B. Nleding and othera, all or those reaults appear to agreo sairly well. As a rogult of thls, only a limlted amount of sampling was required to be done at thig time and conslated of only ifve samples taken from the lower tunnel by the writer, ase1sted by Hax. Max Behrmann in order to learn the value of oertain quartz Bhowings.

The results of this examination and the recomendation baged thereon are given in the accompanying report and on the geologloal plan attrobed to 1 t.

It is a pleasure to state that overy posalble agsiatanoe wae giten the writer by Mr. Behrmann in earriting out thig work.

Yourg Very Trulg,

PWR : W

D. H, RAOEY

Maning Englneer is Goologist 


\section{WORKINGS}

The workings cone1gt of four tunnels eggregating 988 feet of underground work and some twelve or more opencuts that are mostiy oaved in at this time.

The upper tunnel which $1 \mathrm{~s}$ st an elevation of 245 feet above Bea level, has a total of 175 feet of work and exposes the vein 118 sure for a continuous distance of 110 feet. A length of 40 feot. of this ve1n exposed averager blightly over 17.00 per ton in gold across a widh of better than 28 inches but the ontire width of the ore has rot been exposed.

Two short orosecut tunnals, 19 and 31 feot long sospeotively, orosecut the minerel zone at 105 ano 185 peet southerly Irom the portal of the upper tunnel. The more northerly of these exposes a ridth of 9 feet of quartz in 1ta floor from mhloh $\mathrm{Mr}$. Nleding's sample aseayed $\$ 3.50$ and $\mathrm{Mr}$. E. D. stewart's $\$ 9.10$ per ton in gold taken at 35.00 per ounoo.

The lower tunnel 18 at an elevation of 160 peet or 85 feet vert10ally below the upper tunnel. It has approximately 900 feot of workinge and exposes the vein figsures in tro places for 68 feet in each oase. The faoe of the tunnel 1610 feet in the footwall of the vein flesure 60 that a diagonal orosacut 15 to 20 feet long driven toward the north pould bring the drift baok on to $1 \mathrm{t}$.

Between aurvey stations Noa. 1l and 13, or 500 foet in from the portal of the lower tunnel, the main vein fiosure was exposed for a length 68 foet and shows quartz to be 6 foet 10 Inoher wide at one plaoe, whloh a seayed 3.50 over 3 feet 4 in. on the hang1mg wall bide and $\$ 8.40$ ovar 3 peot $61 n$. on the footwall blde; th1s same area having asagyed gold a eampled by Mr. J. C. Roehm of the United gtater Bureau of Mines. (Shoula be Territorial Department of lisnes. BDS) Between this point and the portal of the tunnel the work is in the hanging wall of the veln fiaure, which should be explored by at least two short orosecuta plaoed at 100 foot intervals baok from aurvey stetion No. 12. Greenstone would be out by the Ilsure farther south than that point and it oeemg unlikely that ore would be found in 1 t.

The quartz outorope show plainly 1r openouts orer the upper tunnel and in several additional outs made for a distanoo of 300 feet northerly from the north ond of the upper tunnol. Rowever, the values found by $M r$. Nleding and Mr. stewart in these more northerly outs are low, but a rough compass survey made of them by the writer euggesta thet they may not all be on the main vein fisoure.

The various tunnols and openouts have exposed the main vein flssure from plaoe to place over a alatanoe of allghtly more than 525 peet.

\section{GEOLOGY}

The formation in phicl the ore occurs 1s a limestone os verying dogreer of purity, color, texture and alteration. It is reported to be in the form of a long bolt one-hale mile wido or more and extends for many milos in a northwesterly airection more or less parallelins the Island's coast line. This rook to overlain toward the southwest by a ride bel c: greenstones and

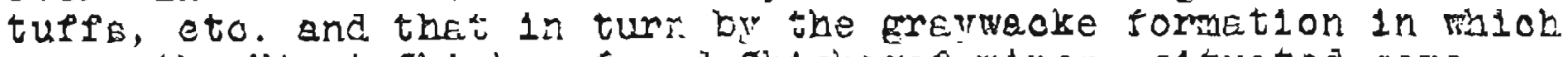
oocur the Hirat-Chichagof and Chichago uines, c1tuated come elfht rlles southerly from the fiew Ohlonggof kining gyndioate'a holdings. 
The 11mestones have boen intruded by numerous dikes and varloualy-ghaped masses of rook thet have been clasg1fied as diorite. These intrusions, in 0 far as could be seen at this time, lay generally in a direction of $N$. $400 \%$, or roughly paraliel to the formation, but they dip at a great pariety of anglea both toward the bouthwest and toward the northeast.

The varlous formationg have been cut by a series of faults and shoar zanas that strike $N 18^{\circ} 30^{\prime} \mathrm{z}$. and dip $60^{\circ}-70^{\circ}$ westerly, one of these 118sures $1 \mathrm{~g}$ partioularly prominent in the mine workings and 18 the avbrue up phloh mineralizing oelutions ascended, probably from the great betholitil of much younger quartz diorite known to exist a mile or so distant toward the northeast.

Th1s particular Ilsare has an apparent hor1zontal displaooment of 50 feet, the east or footwall olde having moved southward and down at an angle of $10^{\circ}$ relatively to the hanglng wall. Th1a fact 18 of lmportanoe when information 18 required regarding what rock 18 I lkelg to be found Immediately abead of the north or south working saoes in the mine.

The mineral-bearing salutions whon asoending this eraoture oarried considerable quartz, a very small percentage of chaloopjrite and pyrite and the gold valuee, all of which replaced the limestone on elther or both walis of the eracture and formed what now are the irregular, lentioular-gbaped and elongated masses of limey quartz that form ore bodles.

It 18 particularis not10eable that no replacoment of the walle matever took plaoe when both walls of the fraoture were composed of diorite, and that oonditione were only partially or very allghtly favourable to replacement when dne wall of the fraoture was composed of diorite, even though the other was of I1megtone. Th1 is Iature appeare to be one of moat importanoe from an economio standpoint and 18 aecond only to the pact that limeat one mugt be present through which the main flesure oen peos before $1 \mathrm{t}$ 1s posalble to have quartz ore bod1e日.

As oan be seen on the acoompanylng geologioal and aragy plan of the mine rorkings, the I1mestone in the visinity of the upper tunnel, and direotly bolow in the lower tunnel, is much out up by diorlte

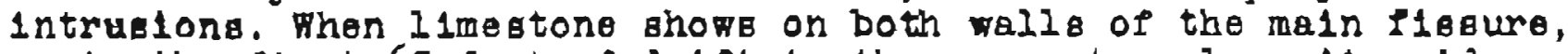
as in the pirat 65 feet of drift in the upper tunnel, quite wide masees of quartz ore have fomed and some of it contalns exoelient values in gold.

Toward the north from the present mine workings it is to be expooted that additional intrusions of diorite will be met for 75 to 100 feot from the north faoe of the lower tannel, after whoh the surface geology, as far as can be seen through the ourface co11, eto. ouggesta that only limeatone ahould be enoountered for many hundreda of feot, consequently, the chanoos of flnding good ore bodies appear very bigh.

The shallowness of the upper tunnel, and the consequent ohanoes of enoountering heavy flows of water make it inadvisable to extend that heading at this time. 
Feturning now to the lower tunnel, it $\$ 111$ be observed, as prev10usly noted, that all workings gouthward from ourvey station No. 11 are apparently in the hanging wall of the main ore-bearing flagure. Al 80 , that the formation southward from station No. 11 is limestone for over 200 feet. Thla area should be explored by everal ahort croseouts, as already pointed out. Howover, it also ghould be noted that there is a marked ohange here in the composition of the limestone, and that 1t 18 much leas pure than toward the north. It is unknown at this t1me hat effect this may have on the deposition of ore along the main fracture beoause at some mining districts such 1mpurities aselst and at otherg they homper the formation of ore bodiea.

It appear $11 k e l y$ that the ore bodies will form in very 1rregular shapes, both in a lateral direotion and up and down the main fiseuring due to the preaence of the above mentioned diorite intrualone. For this reason 1t will be diffioult to bloak out w1th muah degree of certalnty any large amount of tonnage, and when selocting a alte forl ahaft to explore the area at deaper horlzons muoh oareful study should be given first to the general goologioal oonditions, so as to avold as much as poseible those sootions unfavorable for ore deposition.

REOOMENDATIONB

It is recomended that the lower tunnel be extended northward for eeveral hundred feot, boling oareful in dolng so to keop on the main 118aure. Also, that the oamo vein ilosure be explored from the southerly portion of the tunnel by moans of short croseouts spaced 100 feet apart, a proviousig outilnea. These ahould be kept carefully within the limestone, for, as already mentioned, 1 t $1 \mathrm{~g}$ unlikely that any ore $\$ 111$ be formed in the plasure where it paseas through the groenstone that $110 \mathrm{~s}$ to the south of the Ilmestone deporits.

When this has been done, the altuation ahould bo reviewed as to result obtalned, and a new progrem should be lald out which might ine olude a ventilation ralae to the uppor tunnel, further drifting toward the north in the lower tunnel, and poselbly ghaft elniting therefrom. The advisability of this oar be determined only orter the prosent program has been oarried out and the reaulta reoorded.

\section{OONCLUSIONG}

The study and mapping of the geologioal conditions that are just oompleted augget that there 1 a an exoellent chanoe of finding oommercial ore bodles both toward the north and toward the south of the preaent exposuros of the main ven figaure in the lower tunnel, the former appoaring the most promising.

Traneportation and harbor oonditions are good; temperatures in the winter should not be exoesalvely low due to the nearness of the ooean; timber for present mining requirements is avallable on the property; water power could be generated nearby if warranted by the olze of future ore reberver; and supplies oan be obtalned readily from elther Juneau or Beattle by rater.

Ageinet the points are the fects that mining in irregular 11megtone replaoement deposit8 18 uelaliy more expensive than in most other forms of ore deposits; future development and most of the probable produotion will be ma1nly from ghaft operation 1 th 1 to added expenses for bolating and pumplng; and that it will be difflevit, from the nature of the ore deposite, to block out ahead of mliling operations any great tonnage reserves.

Constaerition al al these pointa, coupled with the fact that goodalzed quartz bodies have been formed each time when limestone shored on both walls of the main fiseure, indicates that furcher development 18 warranted and that resulta therefrom may lead to the instaling of a m11.1.

The chanoes for suocess of this undertaking, appear this time to be better than even 


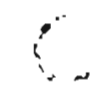

$F_{i}$

\section{CHICHAGOFF KIINIISG COIPANY}

DATA ON HOISTING, SIGNALLING \& VEITTILATING SYSTEMS 


\section{DATA ON HOISTING, SIGHALIING \&. VEIT ILATION SYSTIMS}

Mine Telephons system

All telephones located underground are pestern flectric or stromberg-Carloon Yine Telephones with iron casos.

Telepinone on main system located in compressor House outside.

Mine: Main Tunnel Level:

phones No. 2 Hoist

Fuse House

200 Level

700 station No.2 Shate and at No.3 Hoist

$\frac{2200 \text { LeVeI }}{\text { No. } 4 \text { Hoigt }}$

No. 4 sinaft has another system not connected to main system, with telephone on 1200 Level zt No, 4 Hoiat and on 1400 and 1500 levels at stations.

Ho1st SignaI Systems

The signal systems used in No. 2 and No.3 Shafts consiate of a single stroke bell and light at holgt 2 lso light on ench level for calling aktp. These are operated by mine signal ovitches located on station side of sinft tiroer.

The operating siznal to hoistman is Given by mine eignal switches located in shaft eide of simbers r:1t: pull wires runnine dowr to the next level below. Those operate Benjamin Indugtrial Buzzers located at the hoist and on each level.

The systen in No. 4 shaft is the same except a vibrator bell is used for an operating 6 ienal from 1400 and 1500 levels and the buzzer is operated fror the ginft below 1500.

As soon as the shaft oinking is completed the vibrating bell will be discontinued and buzzers used as operating signals from all levels the same as in the other shafts.

These gystems operated from 220 volt lighting current. 
HOISTS - All operated by compreased air.

No. 2 Sinaft - Skip on Iz1ls.

Ildgerwood No.64 Hoist - $10 \times 12$. double cone friction -

band brake.

Drum 46" Diam. 42" long, grooved for $7 / 8 "$ rope.

Hoistine speed 750 ft. per min.

" "350ft " "witr men on.

No. 3 Shaft - Skip on ra118.

0 \& S Special Loigt $-7 \times 10$, positive clutch on crank shaft, Post brake - Drum $30 \times 4.1$ - Erooved for 5/8" rope.

$\begin{array}{cl}\text { Hoisting speed } & 450 f t \text { per min. } \\ & 330 f t \text { " "with men on. }\end{array}$

No. 4 Shaft - Bucket on Sk1do

L Lidgerwood Hoigt - 6 $\frac{1}{2} \times 8$ - single friction - band brake.

Drum $14 \times 18 \times 5 / 8 "=$ =pe.

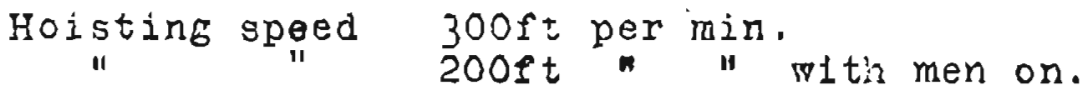

Bucket 29" diam - 36" deep.

simall bucket (not in uge now) 24 H diam. 32 " deep.

Guides

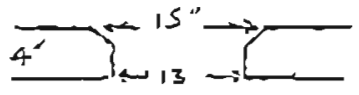

Distance end plate to plpe across shaft $47^{\prime \prime}$

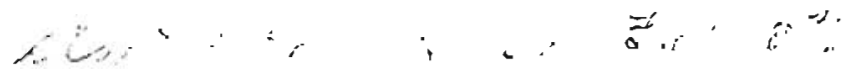


Ventilating Fang.

On 1100 Level - discharging out into drift.

Weatern Blower Co. Ho. 24 - 8" intake and discharge -

Direct connected to motor -1735 R.P.M.

On 1200 Level - discharging into 8 " plpe to 1000 fan.

Sturtevent No.4 - 10H intake and discharge - 2333 RPM.

Belted to 5H.P. motor . 1750 RPM.

Discharge reduced to $8 \mathrm{H}$ to connect to $8 \mathrm{M}$ pipe.

Intake 10N pipe into 1200 orift south of 1401 raige.

Canvas door North of raise.

Fire Doorg

Cloge fitting fire doorg to cut off all draft locatod at mouth of main tunnel and near fuse house betroen No. 1 Shaft and No. 2 shaft.

\section{Compresgore}

Located in compressor bullding 300 ft from mouth of tunnel and comnected to large rock recelver near No.2 shaft by two 4" pipe lines.

Compressors

Two Ingergoll-Rand - $19 \times 12 \times 16,880 \mathrm{cid}$. ft. air per minute - belt driven by 150 H.P. notora.

One Ingergoll-Rand Compregsor - $16 \times 10 \times 14-400 \mathrm{cu}$. ft. air per minute - belt ariven by $100 \mathrm{H}$. P. motor. 
Record of Hine Tempernturea taken "arch 20 th 1933.

\begin{tabular}{|c|c|c|}
\hline outdoora & 38 & 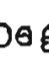 \\
\hline Collar No. 4 Shaft & 70 & $"$ \\
\hline Face 1200 Drift South & 68 & $H$ \\
\hline 1400 Drift (25ft. south of shaft) & 72 & $n$ \\
\hline $\begin{array}{c}\text { " } \quad \text { (5ft, past last raise } \\
\text { from } 1501 \text { atope) }\end{array}$ & 74 & n \\
\hline 1501 stope - 12th floor & 73 & $n$ \\
\hline 1500 Drift - last chute south & 73 & $n$ \\
\hline " Station & 72 & $"$ \\
\hline " face North & 73 & $n$ \\
\hline 700 station - bottom 朝 Shaft & 60 & H \\
\hline 6th floor drift - 1405 Raise & 73 & M \\
\hline
\end{tabular}

